\title{
GENETIC VARIATION AMONG PATHOGENS CAUSING "HELMINTHOSPORIUM" DISEASES OF RICE, MAIZE AND WHEAT
}

\author{
RITA C. B. WEIKERT-OLIVEIRA ${ }^{1 *}$, M. APARECIDA DE RESENDE ${ }^{1}$, \\ HENRIQUE M. VALÉRIO ${ }^{1}$, RACHEL B. CALIGIORNE ${ }^{1} \&$ EDILSON PAIVA $^{2}$
}

\begin{abstract}
'Departamento de Microbiologia, Instituto de Ciências Biológicas, Universidade Federal de Minas Gerais, Av. Antônio Carlos, 6627, Cx. Postal 486, 31270-901 Belo Horizonte, MG, Brazil, fone (31) 3499-2760,

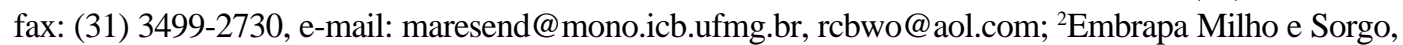
Rodovia 424, km 65, 35701-970, Sete Lagoas, MG, Brazil
\end{abstract}

(Accepted for publication on 10/09/2002)

Corresponding author: Maria Aparecida de Resende

WEIKERT-OLIVEIRA, R.C.B., RESENDE, M.A., VALÉRIO, H.M., CALIGIORNE, R.B. \& PAIVA, E. Genetic variation among pathogens causing "Helminthosporium" diseases of rice, maize and wheat. Fitopatologia Brasileira 27:639-643. 2002.

\begin{abstract}
Twenty isolates of four fungal species, agents of "Helminthosporium" diseases in cereals, were collected from different regions: nine Bipolaris oryzae isolated from rice (Oryza sativa), seven $B$. sorokiniana from wheat (Triticum aestivum), two B. maydis, and two Exserohilum turcicum from maize (Zea mays). The strains were compared by PCR-RFLP and RAPD analysis. Size polymorphism among the isolates in the ITS region comprising the 5.8 S rDNA indicated genetic differences among the isolates, while a UPGMA phenogram constructed after the digestion of this region with restriction enzymes showed inter- and intra-specific

polymorphism. The RAPD profiles indicated an expressive level of polymorphism among different species, compared with a low level of polymorphism among isolates of the same species. A UPGMA phenogram grouped the isolates according to the species and their host plant. RAPD profiles did not reveal polymorphism that directly correlated climatic factors with geographic source of the isolates of $B$. sorokiniana, and B. oryzae. Teleomorphic species revealed high similarity with their correspondent anamorphs.

Additional key words: Bipolaris sorokiniana, Bipolaris oryzae, Bipolaris maydis, Exserohilum turcicum, PCR-RFLP, RAPD.

\section{RESUMO}

\section{Variação genética entre patógenos agentes da doença de "Helminthosporium" de arroz, milho e trigo}

Vinte amostras de espécies de fungos, agentes da helmintosporiose em cereais, foram obtidas de diferentes regiões geográficas, sendo nove constituídas de Bipolaris oryzae, isoladas de cultura do arroz (Oryza sativa), sete de B. sorokiniana coletadas de trigo (Triticum aestivum), duas de B. maydis e duas de Exserohilum turcicum provenientes de milho (Zea mays). As amostras foram analisadas através das técnicas de PCR-RFLP e RAPD. O polimorfismo de tamanho observado entre as amostras na região ITS1-ITS2 e o espaço compreendido da região 5,8S do rDNA indicou diferenças genéticas entre as amostras, enquanto o fenograma construído através do método de UPGMA após a

digestão com as enzimas de restrição, indicaram polimorfismo inter e intraespecífico. Os perfis de RAPD indicaram um expressivo grau de polimorfismo entre as diferentes espécies. Entre as amostras da mesma espécie ocorreu um baixo índice de polimorfismo. O fenograma, obtido pelo método de UPGMA, permitiu diferenciar as quatro espécies analisadas e agrupou as mesmas conforme a espécie hospedeira. Os perfis de RAPD obtidos revelaram ausência de correlação entre os fatores climáticos e a origem geográfica dos isolados de B. sorokiniana e $B$. oryzae. Espécies teleomórficas revelaram alto nível de similaridade com seus correspondentes anamorfos.
\end{abstract}

Several species of Drechslera, Bipolaris, and Exserohilum are important plant pathogens and are associated with symptoms of dark spots on leaves, and root rot of seedlings. These fungi contain dark pigmentation due to the presence of melanin in their cell walls, which is considered an important factor of virulence. The "brown spot" agent in rice (Oryza sativa L.) is Bipolaris oryzae (Breda de Haan) Shoemaker, 1959 [syns. Drechslera oryzae (Breda de Haan) Subram \& Jain, 1966 and Helminthosporium oryzae (Breda de Haan) Miybabe \& Hori, 1901]. The teleomorph of this

*CNPq fellowship species is Cochliobolus miyabeanus (Ito \& Kurib, 1942). The fungal species that attack wheat (Triticum aestivum L.) are Bipolaris sorokiniana [syns. Helminthosporium sativum Pamm., Kim \& Bakkee, 1910 and Drechslera sorokiniana (Sacc.) Subram \& Jain, 1966, teleomorph: Cochliobolus sativus (Ito \& Kurib) Drechsl. \& Dastur, 1942]. The two fungal species that affect corn (Zea mays L.) are Bipolaris maydis (Nisikado \& Miyake) Shoem., 1959 [syns. Helminthosporium maydis Nisikado \& Miyake, 1926 and Drechslera maydis Nisikado \& Miyake, Subram \& Jain, 1966], and Exserohilum turcicum (Pass.) Leonard \& Suggs, 1974 [syns. Helminthosporium turcicum Pass, 1876, Bipolaris 
turcica (Pass.) Subram \& Jain, 1966, and Drechslera turcica (Pass.) Subram \& Jain, 1966]. The teleomorph of these species belong to Cochliobolus heterostrophusm (Drechsler) Drechsler, 1934, and Setosphaeria turcica (Luttr.) Leonard \& Suggs, 1974, respectively (Sivanesan, 1987).

The generic name Helminthosporium is deeply entrenched in the phytopathological literature, and segregation of the graminicolous species into Drechslera, Bipolaris, and Exserohilum has not been accepted universally (Alcorn, 1988). It has been suggested that knowledge of the systematics of the two genera, Drechslera, and Bipolaris, is inadequate (Hawksworth, 1986). The classification of the causal agents of "Helminthosporium" diseases is based on morphological and, to a lesser degree, on biochemical and physiological characteristics (Matsumura et al., 1988). Some authors have used molecular markers to study the relationship among these species (Bakonyi et al., 1995; Abadi et al., 1996).

Increasingly, molecular biology techniques have been used to explore genetic variability in fungi (Caligiorne $e t$ al., 1999a). However, there are still few published studies on the genetic relationships among species that cause "Helminthosporium" diseases (Bakonyi et al., 1995; Abadi et al., 1996). The RAPD technique (Welsh \& McClelland, 1990; Williams et al., 1990) involve the use of arbitrary primers that anneal to genomic DNA at low temperature conditions. This technique detects genetic polymorphisms that can aid in understanding population structure, diversity and taxonomy, and does not depend on prior knowledge of species-specific sequences.

Comparative studies of the nucleotide sequences of ribosomal RNA (rRNA) genes provide the means for analysing phylogenetic relationships over a wide range of taxonomic levels. The nuclear small-subunit rDNA sequences
(16S-like) evolve relatively slowly and are useful for studying distantly related organisms, whereas the mitochondrial rRNA genes evolve more rapidly and can be useful at the ordinal or family level. The internal transcribed spacer (ITS) region and intergenic spacer (IGS) of the nuclear rRNA repeat units, evolve faster, and may vary among species within a genus or among populations. The ITS1 and ITS2 regions represent the most variable region of the rDNA.

This study analyzed genetic variation among fungal agents of "Helminthosporium" diseases isolated from cultures of the cereals rice, wheat and maize from diverse geographic regions. In this study we report the use of PCR-RFLP and RAPD assays as a molecular tool to illustrate the relationship between genetic polymorphism, type of host plant and geographic distribution.

Twenty fungal isolates causing "Helminthosporium" diseases from different regions of North and South America were analyzed, including nine isolated from rice, seven from wheat and four from maize (Table 1). Teleomorph isolates [C. miyabeanus (CM.DO.TEX2), C. sativus (CS.BS.A20), C. heterostrophus (CH.DM.C4), and S. turcica (ST.ET.NK2)] were obtained from international collections and were used as reference for both PCR-RFPL and RAPD tests. Isolates were maintained on potato-dextrose agar at $4{ }^{\circ} \mathrm{C}$.

According to protocol described by Caligiorne et al. (1999a) samples for DNA extraction were grown on potatodextrose broth for eight days at $28^{\circ} \mathrm{C}$. Two grams of mycelia were harvested, frozen in liquid nitrogen and then ground to disrupt cell walls. The pellet was washed three times with phenol-chloroform and precipitated with absolute ethanol and $0.3 \mathrm{M} \mathrm{NaCl}$. After $15 \mathrm{~min}$, the precipitate was centrifuged and washed twice with $70 \%$ ethanol, dried and resuspended in $100 \mu \mathrm{l}$ of $10 \mathrm{mM}$ Tris- $\mathrm{HCl}$ (pH 7.5). DNA aliquots were

TABLE 1 - Characteristics of the fungus species examined

\begin{tabular}{|c|c|c|c|c|}
\hline Species & Host & Source & Origin & Reference \\
\hline Bipolaris oryzae & Rice & Leaf & $\mathrm{GO}^{1}$-Brazil & BO.CNPA1 ${ }^{5}$ \\
\hline B. oryzae & Rice & Grain & GO-Brazil & BO.CNPA2 \\
\hline B. oryzae & Rice & Leaf & GO-Brazil & BO.CNPA3 \\
\hline B. oryzae & Rice & Grain & GO-Brazil & BO.CNPA4 \\
\hline B. oryzae & Rice & Leaf & $\mathrm{SP}^{2}$-Brazil & BO.ESALQ $1^{6}$ \\
\hline B. oryzae & Rice & Leaf & GO-Brazil & BO.ESALQ2 \\
\hline B. oryzae & Rice & Grain & GO-Brazil & BO.ESALQ3 \\
\hline B. oryzae & Rice & Grain & GO-Brazil & BO.ESALQ4 \\
\hline Cochliobolus miyabeanus & Rice & Seed & USA & CM.BO.TEX $2^{7}$ \\
\hline B. sorokiniana & Wheat & Grain & GO-Brazil & BS.CNPA5 \\
\hline B. sorokiniana & Wheat & Grain & GO-Brazil & BS.CNPA6 \\
\hline B. sorokiniana & Wheat & Leaf & $\mathrm{RS}^{3}$-Brazil & BS.CNPT $1^{8}$ \\
\hline B. sorokiniana & Wheat & Leaf & RS-Brazil & BS.CNPT2 \\
\hline B. sorokiniana & Wheat & Grain & RS-Brazil & BS.UFRS $1^{9}$ \\
\hline B. sorokiniana & Wheat & Grain & RS-Brazil & BS.UFRS2 \\
\hline C. sativus & Wheat & Grain & Canada & CS.BS.A $20^{7}$ \\
\hline B. maydis & Maize & Seed & $\mathrm{MG}^{4}$-Brazil & BM.CNPMS $1^{10}$ \\
\hline Exserohilum turcicum & Maize & Seed & MG-Brazil & ET.CNPMS2 \\
\hline C. heterostrophus & Maize & Leaf & USA & CH.BM.C4 ${ }^{7}$ \\
\hline Setosphaeria turcica & Maize & Leaf & USA & ST.ET.NK2 ${ }^{7}$ \\
\hline
\end{tabular}

${ }^{1}$ Goiás, ${ }^{2}$ São Paulo, ${ }^{3}$ Rio Grande do Sul, ${ }^{4}$ Minas Gerais States

${ }^{5}$ Embrapa Arroz e Feijão - GO, ${ }^{6}$ Escola Superior de Agricultura Luíz de Queiroz - SP, ${ }^{7}$ Cornell University, ${ }^{8}$ Embrapa Trigo - RS, ${ }^{9}$ Universidade Federal do Rio Grande do Sul - RS, ${ }^{10}$ Embrapa Milho e Sorgo - MG 
Genetic variation among pathogens causing "Helminthosporium" diseases...

diluted to $20 \mathrm{ng} \mu \mathrm{l}^{-1}$ for RAPD and PCR-RFLP reactions.

The PCR amplification of the ITS regions was achieved by using, the primer-pairs ITS1 (TCCGTAGCTGAACCTGC CG)-ITS4 (TCCTCCGCTTATTGATATGC), comprising the ITS1 and ITS2 spacers and 5.8S rDNA (White et al., 1990). The reaction was performed in a final volume of $20 \mu \mathrm{l}$ containing $40 \mathrm{ng}$ of template DNA, $200 \mathrm{mM}$ of dNTPs, 2.0 $\mathrm{mM} \mathrm{MgCl} 2,2.0$ pmol of each primer and one unit of Taq DNA polymerase (Gibco-BRL, Grand Island, NY, USA). The amplification parameters consisted of 35 cycles of denaturation at $95^{\circ} \mathrm{C}$ for $30 \mathrm{~s}$, primer annealing at $58^{\circ} \mathrm{C}$ for $30 \mathrm{~s}$ and extension at $72{ }^{\circ} \mathrm{C}$ for $30 \mathrm{~s}$. In the first cycle, $3 \mathrm{~min}$ were used in the denaturing step, and in the final cycle, 5 min were added in the final extension step.

PCR products were visualised in silver stained $6 \%$ polyacrylamide gel (Sambrook et al., 1989). The remaining $17 \mu \mathrm{l}$ of the amplified products were diluted at 1:5 in water for endonuclease digestion assays with 12 different restriction enzymes: HaeIII, MspI, HhaI, RsaI, AluI, HpaII, Sau3AI, Taq $\alpha \mathrm{I}$, HinfI, HindIII, EcoRI, and HpaI (Amersham/ Pharmacia Biotech, Bucks, UK). For the restriction assays, $0.5 \mu \mathrm{l}$ of each enzyme (approximately of $0.3 \mathrm{U} / \mu \mathrm{l}$ ) were used together with $10 \mu \mathrm{l}$ of the diluted PCR product and $2.0 \mu \mathrm{l}$ of (10x) restriction buffer One-For-All (Amersham/Pharmacia Biotech). The restriction reaction was done in $3 \mathrm{~h}$ at $37^{\circ} \mathrm{C}$, followed by the extraction of the enzyme with phenolchloroform (1:1). For each experiment, fragment sizes were compared to the size of molecular weight markers included in every gel (100 bp Ladder - Amersham/Pharmacia Biotech).

RAPD reactions were undertaken in $25 \mu \mathrm{l}$ volume containing 1x buffer (Promega Corp., Madison, WI, USA), $0.2 \mathrm{mM}$ each of dATP, dGTP, dCTP and dTTP (Promega), $20 \mathrm{ng}$ of genomic-DNA, $2 \mathrm{mM}$ of $\mathrm{MgCl}_{2}$ (Promega), $0.8 \mu \mathrm{M}$ of primer (Operon Technologies Inc., Alameda, CA, USA) and one unit of thermostable Taq DNA polymerase (Promega) according to protocol described by Caligiorne et al. (1999b). Reactions were carried out using decamer primers from Operon (OPA 01, 02, 03, 08, 09) as well as SOY, RP1-4, RP2 and RP4-2 primers.

To visualise the amplified fragments, $15 \mu \mathrm{l}$ of each reaction mixture was analysed by electrophoresis in $6 \%$ polyacrylamide gels (Sambrook et al., 1989). The gels were run in TBE $(0.45 \mathrm{mM}$ tris-borate, $0.001 \mathrm{mM}$ EDTA $)$ at 150 volts for approximately $2 \mathrm{~h}$ and then silver-stained as previously described (Sambrook et al., 1989). Amplified fragments were visualised and photographed with a Polaroid camera (Model DS-34) with black and white film (type 667, Polaroid Corp.).

The RAPD profiles (bands) that were reproducible in two to three reactions were scored as 0 (fragment absent) and 1 (fragment present) in a data matrix and then, distance values were subject to phenetical analysis using the software package PHYLIP (Phylogeny Inference Package) Version 3.572c. Similarities were calculated by the simple matching method, and a phenogram was constructed using the unweighted pairgroup method analysis (UPGMA) as reported in Sneath \& Sokal (1973).
The PCR fragments generated using the pair of primers ITS1-ITS4 were 580 to 620 base pairs in length. The isolates studied showed length polymorphism in this region of the genome.

Among 12 tested enzymes, only eight revealed digestion of the amplified rDNA. A UPGMA phenogram was constructed after the digestion with the enzymes (Figure 1). The restriction profiles of the ITS region showed an expressive level of similarity among the samples. However, some isolates, BO.CNPA4 (B. oryzae), BO.ESALQ3 ( $B$. oryzae), BO.ESALQ4 (B. oryzae), BS.CNPA5 (B. sorokiniana) and CH.DM.C4 (C. heterostrophus) showed intraspecific polymorphism (Figure 1).

The ITS region of the isolates of $B$. oryzae, BO.CNPA1, BO.CNPA2, BO.CNPA3, BO.ESALQ1, BO.ESALQ2, BO.ESALQ3, and C. miyabeanus, CM.BO.TEX2, isolated from rice revealed two digestion fragments when tested with the enzymes HaeIII, MspI, RsaI, EcoRI, AluI, and HpaII. The isolates of B. oryzae, BO.CNPA4 and BO.ESALQ4 exhibited four digestion fragments when treated with the enzyme Hae III and two fragments with the enzymes $M s p \mathrm{I}, R s a \mathrm{I}, E c o R \mathrm{I}$, and $A l u \mathrm{I}$. The isolates BO.CNPA1, BO.CNPA2, BO.CNPA3, BO.ESALQ1, BO.ESALQ2, and CM.BO.TEX2 revealed four fragments after treatment with the enzymes HinfI, and HindIII. The isolate BO.ESALQ3 generated three fragments when tested with the enzyme Hinfl. The isolates BO.CNPA4 and BO.ESALQ4 revealed three fragments when digested with the enzymes Hinfl, HpaII, and HindIII.

The restriction profiles of the isolates from wheat $B$. sorokiniana, BS.CNPA6, BS.CNPT1, BS.CNPT2, BS.UFRS1, BS.UFRS2, and C. sativus, CS.BS.A20 obtained after digestion with the enzymes HaeIII, MspI, RsaI, EcoRI, AluI, and $H p a$ II exhibited two fragments and four fragments with the enzymes HinfI and HindIII. The isolate of B. sorokiniana, BS.CNPA5 generated two fragments when tested with the enzymes RsaI, EcoRI, AluI, and HpaII. The same isolate revealed four fragments when tested with the enzyme HindIII. The isolate BS.CNPA5 differed from the others, demonstrating three fragments when treated with the enzymes HaeIII, MspI, and HinfI (Figure 1).

The restriction profiles of the isolates from maize, $B$. maydis, BM.CNPMS1, E. turcicum, ET.CNPMS2, and $S$. turcica, ST.ETNK2 generated two fragments when digested with the enzymes HaeIII, MspI, RsaI, EcoRI, AluI, and HpaII revealed two fragments. The same samples generated four fragments after digestion with the enzymes HinfI and HindIII. The isolate C.I heterostrophus, CH.BM.C4 revealed the same profiles obtained by the other isolated from maize when treated with the enzymes HaeIII, MspI, EcoRI, AluI, and HpaII (two fragments) and with the enzyme HindIII (four fragments) but revealed polymorphism when digested with the enzymes RsaI and HinfI, generating three fragments (Figure 1).

A total of 132 different reproducible RAPD markers were generated from the primers. Among the nine primers tested, only six revealed amplifications. However, these 
R.C.B. Weikert-Oliveira et al.

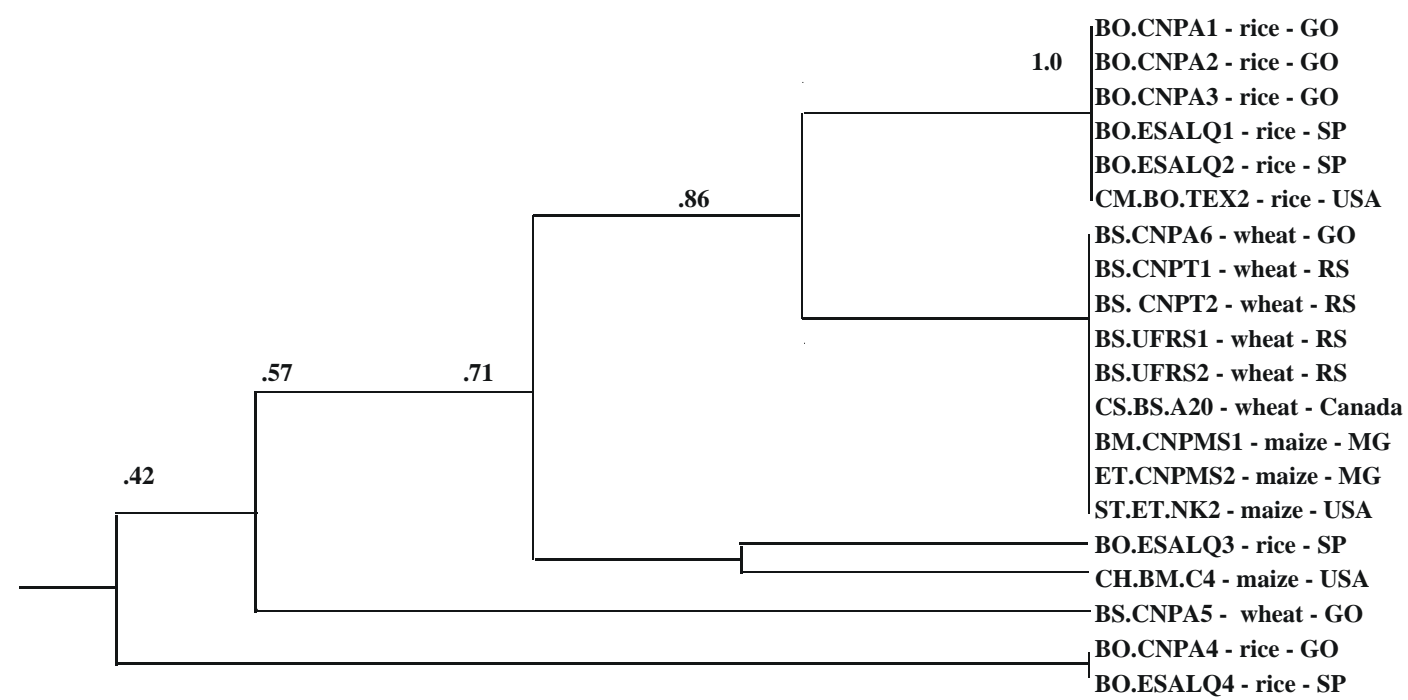

FIG. 1 - UPGMA-phenogram depicting relationships among 20 operating taxonomic units of fungal agents of "Helminthosporium" diseases in rice (Oryza sativa), wheat (Triticum aestivum), and maize (Zea mays) using 41 characters obtained by PCR-RFLP.

primers did provide representative profiles of isolate clusters.

The phenogram obtained from UPGMA is illustrated in Figure 2. The phenon line, representing the mean between isolate similarities, was drawn at $73 \%$. At this level, three groups were characterized: the first included all six $B$. sorokiniana isolated from wheat, the second, $B$. oryzae isolated from rice, and the third B. maydis and E. turcicum isolated from maize (Figure 2).

RAPD profiles of $B$. sorokiniana strains showed an average of $89.2 \%$ similarity while RAPD profiles of $B$. maydis species had $76 \%$ similarity to $E$. turcicum species. Profiles of B. oryzae strains clustered into two groups with $74 \%$ similarity among them (Figure 2).

The PCR-RFLP observed profiles indicated some intraspecific polymorphism within our sampling (Figure 1). These data confirmed occurrence of variability in the ITS region and suggest that this technique is an appropriate tool for studying genetic variability among different populations

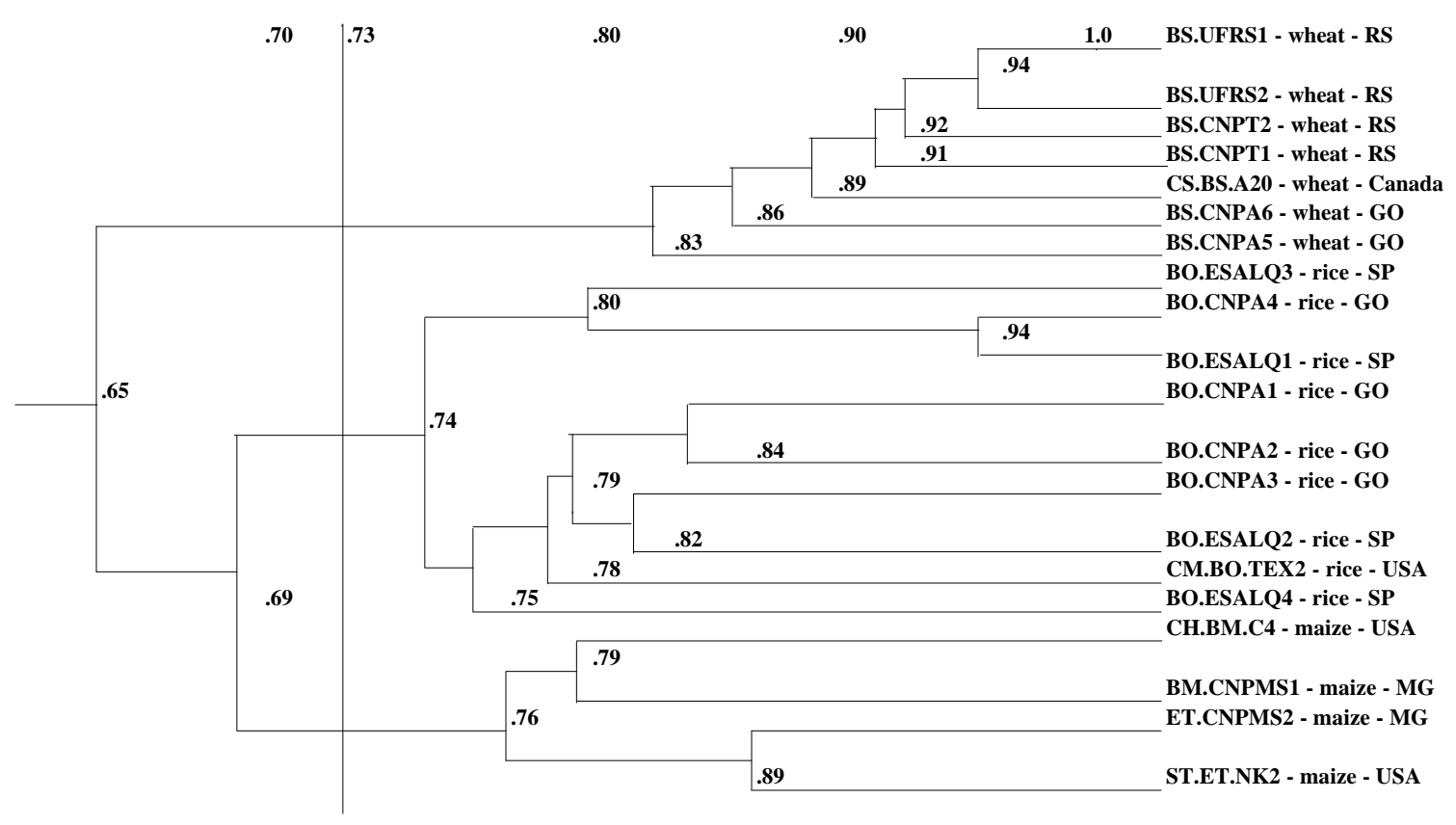

FIG 2 - UPGMA-phenogram depicting relationships among 20 operating taxonomic units of fungal agents of "Helminthosporium" diseases in rice (Oryza sativa), wheat (Triticum aestivum), and maize (Zea mays) using 132 characters obtained by RAPD. 
Genetic variation among pathogens causing "Helminthosporium" diseases...

of "Helminthosporium" diseases causal agents in rice, maize and wheat.

Ouellet \& Seifert (1993) observed that the PCR-RFLP analysis could, in some cases, detect genotypic variations not revealed by other techniques, permiting a more precise comparison of results in the study of phytopathogens. Oliveira (1995) obtained differentiation in the eletrophoretic profiles of ITS region of isolates of $B$. sorokiniana by PCR-RFLP technique.

OPA 01, OPA 02, OPA 03, OPA 08, OPA 09, and SOY primers revealed the best profiles of strains, demonstrating the applicability of these primers for RAPD reactions that seek to analyze species causing "Helminthosporium" diseases in cereals.

UPGMA analysis grouped isolates according to their species and host showing an expressive polymorphism among different species (Figure 1B). This finding reinforces the classification of "Helminthosporium" diseases agents from wheat, rice and maize into distinct genera, further illustrating the validity of this technique for studing genetic polymorphism among different species (Alcorn, 1988; Bakonyi et al.,1995; Caligiorne et al., 1999b).

Our results agree with Matsumura et al. (1988), who analyzed phenotypic relationships among isolates of $B$. sorokiniana collected from two wheat cultures. These authors observed that plant-pathogen specificity was the determining characteristic that contributed the most to the groupings of isolates of this fungus. On the other hand, studies done by Oliveira (1995) with B. sorokiniana isolates identified genotypic variation among the samples.

The phenogram (Figure 1B) shows two clusters for $B$. oryzae isolates. Geographic distribution analysis of B. oryzae samples showed that both the clusters contained isolates from distinct regions, which suggests that there was no correlation between geographical origin and RAPD groupings.

A total of 26 isolates representing 15 species of Drechslera, five Bipolaris and four Exserohilum, and two formae speciales of Drechslera teres (Sacc.) Shoemaker were compared by RAPD analysis by Bakonyi et al. (1995). Drechslera formed a large, heterogeneous group, while species of Bipolaris and Exserohilum were more closely related.

Considering their cultural characteristics and specificity to their major hosts, the results obtained in the present study confirm that species of Drechslera, Bipolaris and Exserohilum are genetically distinct.

The RAPD and PCR-RFLP profiles demonstrated that the teleomorphic forms of the analysed species presented high genetic similarity in their electrophoretic profiles when compared to the respective anamorph of each species.

\section{ACKNOWLEDGEMENTS}

This work was supported by FAPEMIG (Fundação de Amparo à Pesquisa do Estado de Minas Gerais).

\section{LITERATURE CITED}

ABADI, R., PERL-TREVES, R. \& LEVY, Y. Molecular variability among Exserohilum turcicum isolates using RAPD (random amplified polymorphic DNA). Canadian Journal Plant Pathology 18:29-34.1996.

ALCORN, J.L. The taxonomy of "Helminthosporium" species. Annual Review of Phytopathology 26:37-56.1988.

BAKONYI, J., POMAZI, A., FISCHL, G. \& HORNOK, L. Comparison of selected species of Bipolaris, Drechslera and Exserohilum by random amplification of polymorphic DNA. Acta Microbiology Immunology Hungarica 42:355366. 1995.

CALIGIORNE, R.B., RESENDE, M.A, DIAS-NETO, E., OLIVEIRA, S.C. \& AZEVEDO, V. Dematiaceous fungal pathogens: analysis of ribosomal DNA gene polymorphism by polymerase chain reaction - restriction fragment length polymorphism. Mycoses 42:609-614. 1999a.

CALIGIORNE, R.B., RESENDE, M.A., PAIVA, E. \& AZEVEDO, V. Use of RAPD (random amplified polymorphic DNA) to analyse genetic diversity of dematiaceous fungal pathogens. Canadian Journal of Microbiology 45:408-412. 1999b.

HAWKSWORTH, D.L. Fungal genera in urgent need of taxonomic work. Microbiology Science 3:58. 1986.

MATSUMURA, A.T.S., MORAES FERNANDES, M.I.B., PRESTES, A.M., ZANETTINI, M.B.B. \& OLIVEIRA M.A.R. Relações fenéticas entre isolados naturais de Bipolaris sorokiniana: Resumo, XV Reunião Nacional de Pesquisa de Trigo, Passo Fundo, RS. 1988. p. 230.

OLIVEIRA, A.M.R. Estudo da variabilidade genética em Bipolaris sorokiniana utilizando as técnicas de RFLP (restriction fragment length polymorphism) e RAPD (random amplified polymorphic DNA). Dissertação (Mestrado em Fitopatologia) - Faculdade de Agronomia, Universidade Federal do Rio Grande do Sul, Porto Alegre. 1995.

OUELLET, T. \& SEIFERT, K.A. Genetic characterization of Fusarium graminearum strains using RAPD and PCR amplification. Phytopathology 83:1003-1007. 1993.

SAMBROOK, J., FRITSCH, E.F. \& MANIATIS, T. Molecular Cloning: a Laboratory Manual. Vol.1-2 (2nd ed.) New York .Cold Spring Harbor Laboratory Press. 1989.

SIVANESAN, A. Graminicolous species of Bipolaris, Curvularia, Drechslera, Exserohilum and their teleomorphs. Wallingford. C.A.B. International Press, 1987.

SNEATH, P.H.A. \& SOKAL, R.R. Numerical Taxonomy: The principles and practice of numerical classification. San Francisco. Freeman \& Company. 1973.

WELSH, J. \& MCCLELLAND, M. Fingerprinting genomes using PCR with arbitrary primers. Nucleic Acid Research 18:7213-7218. 1990.

WHITE, T.J., BRUNST, T., LEE, S. \& TAYLOR, J. Amplification and direct sequencing of fungal ribosomal RNA genes for phylogenetic. In: Innis M.A. \& Gelfand, D.H (Eds). PCR Protocols. San Diego. Academic Press. 1990. pp.315-322.

WILLIAMS, J.G.K., KUBELIK, A.R., LIVAK, K.J., RAFALSKI, J.A. \& TINGEY, S.W.V. DNA polymorphisms amplified by arbitrary primers are useful as genetic markers. Nucleic Acid Research 18:6531-6535. 1990. 